\title{
The Dynamic Interpretation of Pancasila in Indonesian State Administration History: Finding Its Authentic Interpretation
}

\author{
Wendra Yunaldi ${ }^{1}$ \\ ${ }_{1}$ Faculty of Law, Universitas Muhammadiyah Sumatera Barat, Indonesia \\ wendrayunaldi78@gmail.com
}

\begin{abstract}
Introduction to The Problem: The term interpretation of Pancasila seems rarely used to measure the substance of the Pancasila as the Indonesian nation's weltanschauung. The term interpretation refers to the concept of constitutional and cultural meaning so that the order of civic life is in the same direction and under the paradigm of God, humanity, unity, society, and social justice. After the amendment of the 1945 Constitution, the Indonesian constitution has faced many changes. The changes that occurred are to creating a democratic governmental order. Even though the democratic rule of the government has surfaced, one thing for sure is that Pancasila is strengthening the form of Indonesia's foundation. Because philosophy, enthusiasm, ideas, and thoughts of the nation's life are determined by the underlying weltanschauung.
\end{abstract}

Purpose/Objective Study: This study is trying to find the authentic interpretation of Pancasila based on its dynamic interpretation throughout Indonesian history.

Design/Methodology/Approach: To answer these problems, the method used in this study is normative research with a conceptual approach so that interpretation is obtained by the paradigm built by the nation's founders.

Findings: By referring to library materials, the conclusion that can be drawn from this research is Pancasila, which is misinterpreted rigidly and is state-oriented to castrate the meaning of Pancasila as a public view of life. Then with the strong tendency of legal-formal interpretation so that it eliminates its substantive nature as weltanschauung or national outlook on life so that Pancasila loses its vital in the present state of life in Indonesia.

Paper Type: Research Article

Keywords: Dynamics Interpretation; Pancasila; Indonesian State Administration

\section{Introduction}

History of Pancasila has begun since post-Indonesian independence and continues to this day (Muhaimin, 2013). After the declaration of independence on August 18, 1945, Pancasila had undergone changes and editorial differences. The first text of Pancasila in 1945 was as follows (Latif, 2018b):

1. Belief in the one and only god

2. Just and civilized humanity 


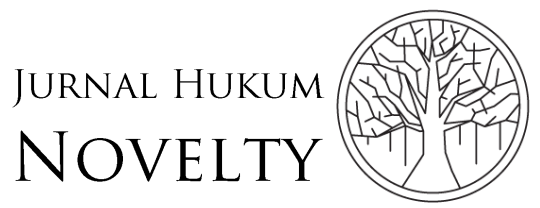

Volume 11, Issue 01, 2020, pp. 39-55

P-ISSN: $1412-6834$

E-ISSN: 2550-0090

3. The unity of Indonesia

4. Democracy that guided by the inner wisdom in the unanimity arising out of deliberations amongst representatives

5. Social justice for all Indonesian people

Four years after independence, there was Republik Indonesia Serikat (RIS) Constitution. Pancasila in the preamble of this constitution had edited and became as follows (Latif, 2018b):

1. Belief in The One and Only God

2. Humanity

3. Nationality

4. Democracy

5. Social Justice

Pancasila, as agreed on August 18,1945, is no longer maintained as the original text. Changes to the 1949 RIS Constitution, perhaps are understandable, due to the interest in creating a federal state to accommodate regional politics as well as a puppet state created by the Dutch. Contrast to its preamble in the 1950 Temporary Constitution, when there were no more disunity and puppet states built by the Dutch, after the absolute surrender towards Indonesian sovereignty. The neglect of the original Pancasila text clearly shows the underlying political problems of the country by the founding father in 1950.

Seven years later, Constituent Assembly in 1957 prepares a new Indonesian grand design, with the discussion of the New Constitution as explained in Article 134 of the 1950 Temporary Constitution. In addition to essential formulations such as a government system, studies on the state principle arise in the arena of Constituent debates. From four speakers from Indonesian National Party (i.e., Partai Nasional Indonesia, abbreviated as PNI), Indonesian Communist Party (i.e., Partai Komunis Indonesia, abbreviated as PKI), Nahḍatul 'Ulamā, League of Supporters of Indonesian Independence (i.e., Ikatan Pendukung Kemerdekaan Indonesia, abbreviated as IPKI). Sakirman, as one of the PKI figures, considers the state principle is the most critical issue in the history of constitution drafting.

With the dissolution of the Constituent Assembly, Soekarno, as the Pancasila decree on June 1, was caught up in a political policy that was in opposition to the Pancasila itself. It was starting from the conception of Triangle Ideologies or famously known as NASAKOM (i.e., Nasional, Agama, dan Komunis), Manipul-Usdek, and Guided Democracy (i.e., Demokrasi Terpimpin), until the dissolution of constituents.

When Suharto became President after Soekarno, he programmed the Pancasila Guidelines (i.e., Pedoman Penghayatan dan Pengamalan Pancasila, abbreviated as P4) (Weatherbee, 1985). He ideologized Pancasila with 36 items and then changed to 46, which was strengthened by the decree of the MPR in 1978. The improvement change had continued in the reformation era. Efforts to construct Pancasila in terms of power 
reoccur with the birth of the phrase 'four pillars' and the Pancasila Ideology Development Board (i.e., Badan Pembinaan Ideologi Pancasila, abbreviated as BPIP), regardless of whether this idea is pure or political.

Pancasila has resulted from deep contemplation, which is in careful research, not a political conception. The characterizing of Pancasila is primarily the living establishment and its outlook. One of the essential functions is to determine the attention to Pancasila as the state principle in forming an independent and sovereign nation (Sujasmin, 2012).

Therefore, the authentic interpretation of Pancasila's principles eventually becomes urgent and strategic. It is because the ideological process that has taken place so far has revealed the views between the seriousness and political jokes of the elite. Pancasila becomes a toy to be proclaimed as a nationalist measure.

\section{Methodology}

This paper is normative research. With a conceptual approach, the author tries to express various views and opinions in government regimes as normalized political subjects through regulations and political policies, starting from the old order era, the new order until the reformation order. By using research material sourced from secondary materials such as council tracts of the Committee of Indonesia's efforts for Independence (i.e., Badan Upaya Persiapan Kemerdekaan Indonesia, abbreviated as BPUPKI) in 1945 and the Constituent Assembly in 1956-1959, books and journals related to Pancasila as a national outlook and primary material in the form of laws and regulations (Marzuki, 2006).

The approach used in seeing the Pancasila interpretation in government and society policies is conceptual. That is an approach that moves from the views and doctrines that develop in the science of law. This approach is important because the understanding of the views that develop in the science of law can be a platform for building legal arguments when resolving legal issues. Through this doctrine thus will clarify ideas by providing legal understandings, legal concepts, and legal principles that are relevant to the problem.

The materials are collected through documentation, both secondary and primary, then formatted so that it can be understood Verstappen or interpretative understanding from the perspective of historical experts. Then, the built-in understanding and perception are analyzed deductively and comparatively.

\section{Results and Discussion}

\section{Pancasila and the Regime's Political Resistance in the History of Indonesian State Administration}

Pancasila was formally established on August 18, 1945, the day after Indonesia's independence was proclaimed. The idea of the basis of the state became a heated 


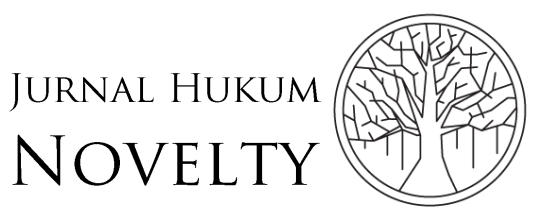

Volume 11, Issue 01, 2020, pp. 39-55

discussion in the sessions of BPUPKI. It is because some of BPUPKI's members, such as M. Yamin, Soepomo, Hatta, Ki Bagoes Hadikoesoemo, and Soekarno, stressed the importance of the primary presence of the state to sustain the building of the Indonesian state (Polamolo, 2018).

Realizing Indonesia as an independent state, the articulation of independence must begin in the foundation or principle of the state. A country with an abundance of independence has no state principle because the state follows the tendency of the basic form of the state, which gives its independence. The construction of independence thinking put forward by the founding father must be manifested through the presence of a state principle that shows an attitude of rejection and, at the same time, differences with the colonial state.

Formally, the idea of Pancasila was born in the council process of BPUPKI which began from May 29 to June 1, 1945. Five members of BPUPKI who gave their thoughts were related to the country's foundation, namely M. Yamin, Soepomo, M. Hatta, Ki Bagoes Hadikoesoemo, and Soekarno. These five people were quite intense in giving their ideas related to the foundation of the country, which was then concluded by Soekarno with the name Pancasila.

M. Yamin was the first figure to give an idea of the state principle. However, in the A.B. Kusuma's notes, the notion proposed by M. Yamin is not in the sense of philosofische grondslag (Kusuma, 2004). But in M. Yamin's notes and the council tract compiled by Saafroedin Bahar quoted from M. Yamin's records, it can be read about the state principle stated by Yamin. Another side, there is a similarity between the concept of M. Yamin and Soekarno, and this is not surprising because, before the reading of the speech on June 1, 1945, Soekarno came to M. Yamin's house (Isdiyanto, 2019).

In a statement on May 29, 1945, Yamin conveyed 5 (five) state principle and the intent of the foundation itself (Hardinanto, 2017). Those five principles are:

1. Nationality

2. Humanity

3. Deity

4. Democracy

5. Social Justice

The idea of the state principle conveyed at the hearing on May 31 by Soepomo. Soepomo stated how necessary the ideal conditions of a country and how would the foundations of the Indonesian state be. Before starting the state principle, Soepomo described the conditions of the state, the people, then the problems of the state and religion and the form of government: republic or monarchy. Related to the country's foundation, Soepomo put forward several points of his thoughts, such as:

1. Unity

The conception of unity refers to the German and Dai Nippon states. German principled to das Ganze der politischen Einheit des Volkes was based on the 
principle of equal blood or race and national landscape or regional equality (Blut und Boden) (Klinke \& Bassin, 2018; Lovin, 1967). Meanwhile, the Asian nation is the Dai Nippon State, which is based on the eternal union of the soul and spirit between the Venerable Tenno Heika, the nation, and the people as a whole. It is called "Koshitu," the state with the family principle (Azhari, 2017). The basis of unity and kinship is very much following the style of Indonesian society.

2. Kinship

It means that the relation of state countrymen, both leaders, and people, is filled with spirit cooperation. Cooperation only grows through the sense of kinship, where one of another has a feel to lean to each other. Therefore, this familial basis is much compatible with the Indonesian people's inner spirit and their spiritual culture.

3. Physically and Spiritually Balance

The balance of physically and spiritually arises from the original social structure is none other than the creation of Indonesian culture. It could be tracked down from the folk saying 'manunggaling kawula gusti' (the unity of God and us). It also means the agreement of the external-inner world, the microcosm-macrocosm, and the people-leader.

4. Deliberation

The rationale for deliberation arises from the spirit of the village head or the head of the people obliged to carry out the conviction of the people's justice. It is the duty to always give a sense of justice and the ideals of the people. Therefore, the village's head must always consult with his people in any decision. By doing so, the intimate relationship between the two is always maintained.

5. Social Justice

The thought of people's justice is a totalitarian nationality based on the understanding of the state as the unity of the Indonesian people. It is composed from an integrative legal system, where the state will manifest and act as the organizer of the conviction of the people's justice entirely. Thus, the social justice for all people will occurred. The state can only be fair if it carries out a sense of justice and leads the people to noble ideals through the times.

Moh. Hatta, in his presentation about the state principle on May 31, 1945, did not elaborate one by one but described it philosophically about the concept of unity in the state. The idea of integration is not intended to unite religion and nation. Religious affairs, according to Hatta, must be separated from the state. Hatta was more consistent with the establishment of a united national state in the totalitarian sense, namely a country that would not unite all groups and would heed and respect the privileges of all groups.

On the opposite of the previous national figures, Ki Bagoes Hadikoesoemo quite firmly conveyed about Islam as the state principle. He stated the Islamic teachings and its faith system. He proposed that Islam as a religion and living law must be applied to its followers (Fajar, 2018). 


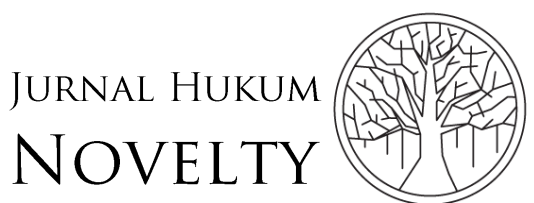

Volume 11, Issue 01, 2020, pp. 39-55

P-ISSN: 1412-6834

E-ISSN: 2550-0090

By addressing Muslim as the 90 percent majority, Ki Bagoes was considering Islam as the state principle, as he said:

"Therefore, gentlemen, as a genuine Indonesian, my father and mother are Indonesian, my ancestors are also original and pure Indonesian. Also as a Muslim, who has the ideals of a Greater and Free Indonesia, so that an independent Indonesian state can stand tall and firm, strong and sturdy. I do hope that this Indonesian state will be based on Islam. Because, that is what is lies under most people's soul" (Bahar, 1998)

In the fiery speech on June 1,1945 , Soekarno managed to arouse the enthusiasm of all participants of the council. The narrative that was so burning with enthusiasm with a weighted material managed to pique all the participants. The long speech was started by interpreting the concept of independence as political independence:

"Politieke onafhankelijkheid is independent, which has a difference with its contents. Germany is free, Saudi Arabia is free, Iran is free, China is free, Britain is free, Russia is free, Egypt is free. All of the names are free and independent, but kindly compare the (each) contents. Independence is, therefore, nothing but a bridge, a golden bridge" (Bahar, 1998)

The first principle said by Soekarno is nationality or by his term satu nationale staat (Notosutardjo, 1965). He speeched:

Indonesian Nationality is the one and only! Not the Javanese, not Sumatranese, not the Borneo, Sulawesi, Balinese or others. But only one Indonesia, which all together being a pillars as a nationale staat. The nationality we advocate is not selfness nationality, not chauvinism, as people were ignited in Europe, who said "Deutschland uber Alles," or none as high as Germany (Bahar, 1998)

The second principle stated by Soekarno was internationalism. Internationalism cannot flourish if it is not rooted in nationalism (Bahar, 1998). Internationalism was intended by Soekarno as a form of a family of nations.

The third principle is the basis of consensus, the basis of representation, the basis of deliberations. The basis of deliberation for Soekarno is a place for Islam, Christian, and other religions to submit formulations that are under the provisions of their religions. In the representation of the people, the brothers of Islam and Christian work as great as possible (Bahar, 1998).

The fourth principle is the principle of welfare; there will be no poverty in Indonesia. The spirit of prosperity expressed by Soekarno was strengthened by his statement:

"Whether we wanted Indonesia to be independent, whose capital people were well-off, or that all the people were well-off, that everyone was well fed, clothed, lived in prosperity, felt in the hands of the Mother Earth which sufficient to provide food to them" (Bahar, 1998). 
Soekarno rejected western democracy, because, the western democratic parliamentary model based on equal rights was unable to encourage welfare for his people, which Soekarno called the sociale rechtvaardigheid. Therefore, Soekarno offered that Indonesia's democratic system was not a Western democracy, but a lifegiving deliberately, namely politiek-economische-democratie. Through the concept of deliberation, which together with the society embodies two principles, namely the politieke rechtvaardigheid dan sociale rechtvaardigheid (Bahar, 1998).

The fifth principle is the deity, which is not only national, but each Indonesian person also has his own Lord God. The understanding that Soekarno wanted to build was related to the deity principle. It was a deity that was cultured, a good deity, a deity that respected one another (Bahar, 1998).

The basic conception of Pancasila, which was said by Yamin, Soepomo, Hatta, Ki Bagoes Hadikoesoemo, and Soekarno, originated from the values that lived in a society. Yamin refers a lot to the original life model of society as Soepomo. While Hatta with the understanding of totalitarian unity. In contrast to Ki Bagoes Hadikoesoemo, who firmly covered his thoughts from the conception of Islam. Even though Soekarno referred to Eastern thought models, that did not necessarily make Soekarno copy those thoughts. Soekarno firmly chose an alternative path through the perspective of native Indonesian culture.

The last seconds before it was dissolved in 1959, Pancasila was again confirmed as the Fundamental Norms of the Republic of Indonesia (Attamimi, 1990). However, after the state principle formulation, it was questioned again thrugh debates between tha Pancasilaists, Islamic group, and Socio-Economic group. What Soekarno declared through the Presidential regulation on June 1, 1959 was no more than a form of abuse of power using the Jakarta Charter on June 22. In the preamble of the decree, it is stated that the Jakarta Charter on June 22, 1945 ensoul the 1945 Constitution and it is a series of unity with the constitution (Shaleh \& Wisnaeni, 2019).

Within almost 14 years (1945-1959), Soekarno, as President with absolute authority in his hand, the implementation of Pancasila should be stronger in state life. The genuine thought of Pancasila in Soekarno's mind was adequate to provide a place for Pancasila in governing the country. However, it was ultimately unable to defend the Pancasila under political conflict within the country. Thus, Soekarno failed to 'enclose' himself with the ideological conception he made himself on June 1, 1945, with Pancasila.

Soekarno's ideas related to Panca Azimat, which he had compiled from 1926 to 1965, were used as a revolutionary spirit to overcome all Indonesian problems and roots in the shortest possible time towards a just-prosperous society. But still, it was experiencing a shift from the true essence of Pancasila (Siswo, 2014). 


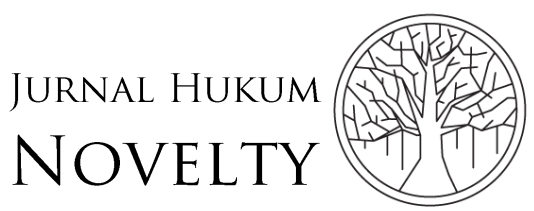

Volume 11, Issue 01, 2020, pp. 39-55

P-ISSN: 1412-6834

E-ISSN: 2550-0090

The first azimat is Nationalism-Islamism-Marxism, which was written in 1926. Soekarno saw, in his article published by Soeloeh Indonesia magazine, the potential of the three ideologies as a glue for unity, and as an absolute condition for independence. The second azimat is Pancasila on June 1,1945, as the nation's ideology that was formulated as the preamble of the 1945 Constitution. The third is the Rediscover of Our Revolution (1959), which was started as a political manifesto. The fourth is Trisakti in 1964. The last azimat was the firm stand of self-independent in 1965. The Panca Azimat were only Soekarno's compilation, the first two from the reality of Indonesian society and the last three from the August 45 revolution event (Siswo, 2014).

The NASAKOM idea of Soekarno, when he shouted in his speech, "we must all be Nasakomists," then led his government to September Revolution (Notosutardjo, 1965). It is the mark of the failure to penetrate the Pancasila within the elites. The involvement of the Indonesian Communist Party (i.e., Partai Komunis Indonesia, abbreviated as PKI) in the Pancasila Block and was intensively involved in preparing the state principle, contrasted with the political practice on the ground that they did. The PKI continued to build extensive social power on the people in various regions. In fact, they weakened the Pancasila an ideology. Instead of supporting the ideology, PKI continuously campaigned for socialism-communism as an ideology for the proletariat. Their massive campaign was encouraged by Soekarno's idea of NASAKOM, in which any opposition was deemed anti-revolutionary (Soedarmo, 2014).

Here lies the difference between the PKI movement and what was largely done by the Masyumi Islamic group, which opposed Soekarno over his inconsistency in Pancasila. Natsir and his friends preferred to oppose the Soekarno regime as a form of 'awareness movement' for Soekarno. Natsir did not reject Pancasila as a result of the BPUPKI in 1945, because it was the successful culmination of the Indonesian people, especially Muslims. The choice of the agreement is a step forward in seeing the interests of the nation first. Therefore, according to Natsir in his writings, "in the lap of the Quran, Pancasila will flourish, one another not a priori, contradictory but not identical (the same) (Gunawan, 2000).

After Soekarno's regime, Suharto government after 1965 was trying to revise the application of Pancasila as an ideology in the life of the nation and state. Perversion of Pancasila became the reason of Suharto's regime to castrate Soekarno's political movement and his loyal accomplices.

To strengthen Soeharto's version of Pancasila, he decided to emphasize the position of Pancasila, through the Act No. 5 of 1985, as the only principle for all organizations and political parties in Indonesia. By using Pancasila, Soeharto succeeded in strengthening the hegemony of power sustaining the implementation of development programs under state-centered control, until his fall in 1998. Through Soeharto's sole 
principle program, eventually, Pancasila was no longer just a foundation or ideology nor state philosophy, but turned into a myth that was considered higher than religion. It should not be criticized or protested, let alone changed or rejected (Syihab, 2012).

Since the reformation in 1998, rethinking to reformulate Pancasila had only taken place in 2018. After 20 years, Pancasila has begun to move towards the end of ideology, living in a hurry waiting for the helping hand of the rulers. Even though Habibie in euphoria reformation spirit continued to hum the Pancasila, the effort failed to attract the sympathy of the reformers who lived too long in the grip of the feudalistic and dictatorial Pancasila.

The less accommodating response impacted on the search for new identities carried out by the Chairman of Indonesian MPR Taufik Kiemas through a practical-operative approach by giving birth to the concept of four pillars. The four pillars that were rife during Soesilo Bambang Yudhoyono's reign were later canceled by Constitutional Court Decision No. 100/PUU-XII/2013, which in its consideration stated:

"Normative theoretically, it can be undertood that Pancasilai is the state principle, state philosophy, fundamental principles of the state, and the ideal legal principle. So, the 'four pillars' term which include Pancasila as one of it in addition to the 1945 Constitution, Bhinneka Tunggal Ika, and the Unity of Republic of Indonesia is inapropprate and does not have a constitutional juridical base."

Although the phrase 'four pillars' has been canceled by the Constitutional Court, but in practice, it is still used by the MPR and the House of Representatives. The relation between Pancasila, the 1945 Constitution, the Unity of Republic of Indonesia and Bhinneka Tunggal Ika cannot be accounted for in the context of historical, juridical, and philosophical relations. The term 'four pillars' has confused and delegitimated the essential relation and meaning each other in the life of nation and state.

The use of state instruments to revive Pancasila is getting stringer with the birth of Pancasila Ideology Development Board in 2018. The board legalized by Presidential Regulation No. 7 of 2018 which such duties like assisting the president in formulating the policy direction of Pancasila ideology development, coordinating, syhchronizing, and others.

Even though it still not optimal, because it has only been established for more than two years, the impact of horizontal conflict is inevitable. Pancasila was made into a style of power to expose symbolization; (1) anti-Pancasila, (2) anti-Indonesian Republic, (3) radicalism group, and (4) intolerant group.

From the long journey dynamics of Pancasila ideologization, the tendency of power hegemony and its supporters tends to be more dominant than the development of a common national platform. It happens because the structural-regulative approach is more advanced than the cultural-ideological approach. What happened next like 


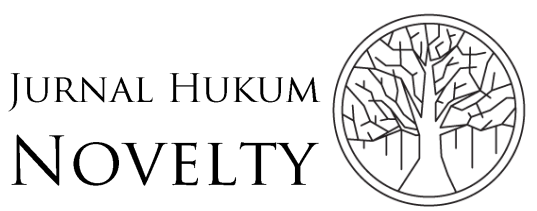

Volume 11, Issue 01, 2020, pp. 39-55

intolerance between religions, blasphemy, violence, violations of human rights, separatist movements, forced coercion, and increasing poverty became a sign that Indonesian society was getting further away from identity-based on Pancasila values (Hastangka, Armawi, \& Kaelan, 2018).

The basic foundations of the Pancasila principle consist of two, first, a moral foundation, that is Belief In The One And Only God, and second, a political foundation, that is humanity, the unity of Indonesia, democracy, and social justice. The five elements listed in the Pancasila are not new things that arise in the formation of Indonesia, but before and forever have been owned by the Indonesian people, who exist and live in the souls of the people and nation of Indonesia (Dayanto, 2013).

In the historical development of Indonesian state administration, the dynamics of the Pancasila interpretation cannot be denied that they have experienced a shift from the state's ideology and principle. According to Moh. Mahfud MD, Pancasila can be seen from at least 3 (three) aspects: political, philosophical, and juridical (laws and regulations) (Anggono, 2019). Based on the three approaches of Mahfud MD, the entire set of state power journeys must be truly following the political, philosophical and juridical framework which must lead to Pancasila.

\section{Analysis of Authentic Interpretation of Pancasila Construction in Strengthening National Identity}

Our return to the original Indonesian legal system which the author calls Authentic Law does not mean that we are becoming old-fashioned, anti-change, and also antimodernization (Yunaldi, 2019). With the position of Pancasila as a source of law, Pancasila is a source of law that is compiled based on a moral system and legal order that is embedded long in the history of Indonesian civilization.

The formation processes of Pancasila by the founders of the nation, with the variety and characteristics of religious, social, humanitarian, justice and wisdom, have shown Pancasila to be feasible as a thought (Bo'a, 2018) and at the same time become a patron of national and state life. As a thought, Pancasila itself contains the principles of morality and national vision. The people's vision that is accommodated in Pancasila, begins by compiling it in the form of wisdom and points of Pancasila. The points of the Pancasila are correlated with local wisdom and its cultural behavior shows the values in society. According to Yudi Latif:

"Pancasila, as it seen by Soekarno and the other founding fathers, is more fulfilling human needs and more saving people than the United States Declaration of Independence or the Communist Manifesto. Declaration of Independence does not contain Social Justice; As for the Communist Manifesto, it does not contain a Deity (must be sublimated with a Godhead) so as not to be imprisoned in materialism image" (Latif, 2018a)

In the perspective of Adat law, as Wendra Yunaldi's research states, "realistic conceptions of Adat law position are important for upholding the ideals of the 
Indonesian state law (Yunaldi, 2018). This means the values that are covered and practiced by adatrecht (adat) are living potential sources in society as an order of morality, both as an order of morality and law.

Pancasila with its moral dimension and as a fact that lives in the society, becomes a vision for the Indonesian people. This vision was referred by Soekarno as 'Philosofisches Grondslag' (Notosutardjo, 1965). In the ideology perspective, Alvin Gouldner separates ideology from the mystical awareness of religion, he justifies desirable actions, through logic and evidence he shows the need of an ideological view of the social world, beyond the faith, tradition, revelation or language authority (Kaelan, 2015). Astim Riyanto quoted Notonagoro's opinion, saying that what was stated in the Pancasila were not new things that had arisen in the formation of the Indonesian state, but had previously been and forever owned by the Indonesian people (Riyanto, 2007). Pancasila, therefore, has its own 'character value' that came from the social system of Indonesian society.

The development of Pancasila's interpretations, from Soekarno, Suharto, to the reformation regime, are not strengthening the Pancasila values in Indonesian people. The structural approach taken by the state has widened the gap between das sein and das solen, expectations with reality are not integrated. Public perception of the truth from Pancasila ideology as 'one acceptable word,' among the diversity of ethnic groups and religions fails to be fixed by state's interpretation. From social ideology point of view, Pancasila requires an interpretation that accommodates the potential for national plurality without having to be trapped in scientific symbolization which is forced as 'open ideology.' Following the formulation, each nation will experience progress towards the future, then the future of Indonesia will be different from other nations when Indonesia can maintain the values that have been formulated as cultural ties (ideology).

To keep this nation remains to stand tall, Pancasila must be interpreted moderately, so it will not become a blunt knife. Haedar Nashir Chairperson of Muhammadiyah states:

"This Unitary State is an entity that forms itself in a unity which Soekarno easily constructs it in a state and nation. The unity whose buildings stand tall on Pancasila as 'basic philosophy' (philosofische grondslag) and 'view of life' (weltanschauung) which is the center of the local point meeting of all the diversity gathered in the spirit of Gotong Royong. This meeting point becomes a moderate force in the body of Indonesia; thus, it can conclude that Indonesia with all its Indonesian aspects which bound and based on Pancasila is actually moderate. Therefore, Indonesia should not be withdrawn and deflected to become radical, extreme, and deny its moderation" (Nashir, 2019)

The coherence of Pancasila's interpretation needs to stand as values, beauty, and goodness with a moderate approach, as well as being strengthened by authentic traditions that apply to society. It is because the flow of thoughts that developed in 


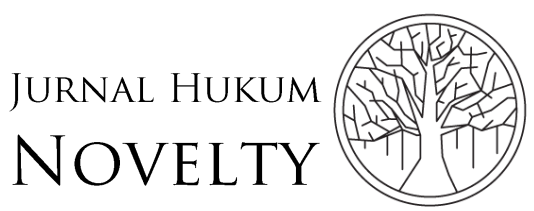

Volume 11, Issue 01, 2020, pp. 39-55

P-ISSN: 1412-6834

E-ISSN: 2550-0090

the formulation of Pancasila on May 29 to June 1, which was appointed on August 18, 1945 , is a systemic-exclusive series of capturing cultural values that live in the archipelago and empirical experiences that took place at BPUPKI which later strengthened by the Jakarta Charter on June 22 .

The values of Pancasila which include the values of God, humanity, unity, society, to justice, must be translated into variables and indicators that are easily applied in society. The applicative side of Pancasila as mentioned above will be easily realized if Pancasila itself is open and dynamic (Maharani, Surono, Zubaidi, \& Sutarmanto, 2019).

Bambang Sumardjoko, saw that the peak of the socio-cultural life of Indonesian people became the life order foundation of society which called the view of life. Therefore, the values of Pancasila appear from the socio-cultural life of Indonesian people, such as (1) the belief in God Almighty as the Creator and Protector of the universe; (2) the principle of family, mutual love as a family, father, mother, and children. This love and kinship form the basis of the formation of society; (3) the principle of deliberation to reach consensus. Togetherness is a collection of many individuals, citizens, and families. (Bambang Sumardjoko, Revitalization of Pancasila Values Through Local Wisdom-Based Civics Learning for Strengthening National Character and Identity, 2013; 110-123). Related to this matter, Pancasila also provides boundaries, norms, and direction for a policy of the state implementation, also in terms of determining the policy of the state direction. Therefore, Pancasila is not only legal but also norms and direction for the implementation of state policy.

The P4 interpretation model created in the New Order regime tends to have supra values. Where the formulated values are published from understanding and logic and the truth of power, without referring to the social order of society. Through the revocation of $\mathrm{P} 4$, new formulations need to be presented so no value gap is agreed upon nationally by a pluralistic society. This needs to be done so that Pancasila can be implemented as a state principle consistently by the people of Indonesia. This is in line with the expectations of Article 1 of the TAP MPR/XVIII/1998 (Siswanto, 2017).

Seeing the efforts from philosophical, sociological, cultural paradigm, to make an authentic interpretation of Pancasila must be carried out with the following reasons:

1. Pancasila was born from the cultural system of the Indonesian archipelago, from Sabang to Merauke.

2. Pancasila is an objective and subjective reality of a society that has been developed for a relatively long period.

3. The values practiced by the people in various cultural layers have been tested for validation in the social fabric of society.

4. Pancasila is accepted as a 'national view' because its values are under the perspective values adhered to the cultural system, religious system, political system and individual ideological system of society. 
5. The values of Pancasila have a close relationship with the socio-psychological and socio-values of society.

Based on the reasons above, the authentic interpretation from the author view is how the formulation of Pancasila must be released from political, elitist and historical tendencies, such as:

1. Political-elitist approach;

2. Cumulative-generative approach;

3. Regulatory constitutive approach;

4. Structural-political approach; and

5. Numerative approach

It is because the above approaches that have been carried out by the state tend to place Pancasila as an object of state, group, and individual interest, so none of these interpretations can answer the nation's strategic needs. In the perspective of authentic interpretation, Pancasila must be placed not as a source of legal norms that tend to be positive. Pancasila must be placed as a norm with a unified whole value in sustaining the entire creativity, taste, and intention of Indonesian people.

Through the process of ideologization towards Pancasila by ignoring its philosophical principles, it will place Pancasila as a political idiom that is the lack of a rational understanding of cultural, religious, and ethnic diversity. Pancasila must be built with those three understandings because Pancasila is part of the 'the values equality' found in culture, religion, and ethnicity that has sustained the social security of society so far. Thus, Pancasila is not an open ideology that can be drawn based on political, ideological, religious tendencies, and based on the interpreter's interests.

Sidharta said that Pancasila is a philosophical foundation in arranging the framework and basic structure of state organization as formulated in the 1945 Constitution (Buamona, 2017). The philosophical formulation in the body of 1945 Constitution arranged so it becomes a normative reference in shaping the Indonesian constitutional system.

Therefore, the authentic interpretation of Pancasila must be built through an authentic paradigm as it develops in various councils and debates in BPUPKI and the Constituent Assembly. Thus, it will clarify how the ideal construction of Pancasila in organizing the state administration and social structure of Indonesian society.

Regulation in the structural and social aspects refers to several rules of thinking, such as:

1. Restore public awareness of Pancasila as the accumulated value practiced by society.

2. Using the themes that compiled in the interpretation of Pancasila is the collective awareness of the society itself. 


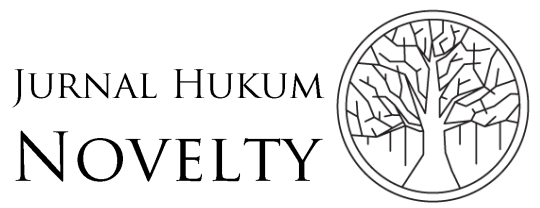

Volume 11, Issue 01, 2020, pp. 39-55

3. The use of styles, perspectives, approaches, and rules contained in culture, ethnicity, and religion must be the exclamation point for Pancasila. Thus, they are immediately understood as the values of the nation.

4. Efforts to elaborate Pancasila must be done deductively. Therefore, the reality faced by society conical to every precept, as the pyramid.

5. It is necessary to build an intrinsic sense of belonging of Pancasila to the society.

According to the author, the authentic perspectives above need to be tested. It is because the single interpretation approach made by the state so far has proven to be misunderstood by the society, either because it is too super-reality or because it is not based on reality-objectives faced by the society.

Compilation of the Pancasila's interpretation so far has not succeeded in creating a 'soul' building of Indonesian constitutional system. It can be seen from how easily Pancasila used as a political power style, so it is losing its main function as the joint of the nation. In fact, the 1945 Constitution, the Republic of Indonesia, the People's Sovereignty, Democracy, and the National Goal can survive through the times if it built by solid foundation. The changes can only be enforced by adjusting the philosophical values of the national ideology which is interpreted as the original values of the nation that contained in Pancasila (Mahanani, 2019).

Thus, Pancasila is actual, dynamic, anticipatory and always able to adjust the times, science and technology and the dynamics of the development of people's aspirations. The openness of Pancasila ideology does not mean changing the basic values contained in it, but it makes its insight more concrete. Therefore, it has a reformative ability to solve actual problems that always develop along with the aspirations of the people (Agus, 2016).

The interpretation of Pancasila with its various approaches is dynamic according to the availability of civilization, technology, social, economic, political and globalism resources. Everything becomes a comparative material to increase the positive articulation of the values order of Pancasila. Thus, Pancasila does not lose the context through the time. It means the ability of Pancasila to respond the problems time by time. It is not because of its openness, flexible or dynamic, but rather, the principle that lied in Pancasila itself within the social establishment which is emitted by divine awareness, humanity, wise leadership, and justice.

Moreover, the values contained in Pancasila are universal, which is fought by almost all the nations of the world. The basic values contained in Pancasila have the durability and ability to anticipate the times (Nurtjahyo, 2007). Towards those principles, Indonesia can be maintained as a great state that stands firm on the values that are built on the consciousness of the soul and the mind to live in a different order from other country's ideology and conceptions of the state. 


\section{Conclusion}

Pancasila which is the state principle was compiled based on the philosophy of the Indonesian nation which had lived centuries ago and crystallized in the form of the way of thinking and acting in society. Conceptually, it has been tested and criticized by the nation's founders through comparison with the system and value order of other nations in the world. With the birth of the Republic of Indonesia on August 17, 1945 , with the choice of the constitutional state such as res publica and democracy with a written constitution, several sides have experienced remarkable progress. Institutional progress and an equal relationship model of institutional relations can strengthen the implementation of state power democratically and aspiratively. The progress, as befits large countries that are bound by the ideology of their people, must be a solid foundation for the Indonesian nation so that the constitutional achievements can be maintained.

The direction of authentic interpretation must be built on the cultural, moral, and unity approach that has accumulated in the Pancasila itself. The single interpretation of Pancasila which is political-structural must be changed by prioritizing the perspective of the originality of social values that live in society: customs, culture, ethnicity, and religion. It is done to make Pancasila as a social order of Indonesian people who are truly at home and live within the society's heart.

As weltanschauung, Pancasila management institutions must be above all institutions, groups and political interests. So that Pancasila is not only used as an instrument of political power. The management, paying attention to the development of Pancasila, must be in the form of a national council or commission which stipulated in the 1945 Constitution and then regulated by law. Various forms of institutionalization of Pancasila which formed by the basis of the political power of the regime, have shown its failure to become a national commitment. Therefore, it needs to be reconsidered by the presence of institutions such as the BPIP, both in terms of structural governance and social society.

\section{References}

Agus, A. A. (2016). Relevansi Pancasila sebagai ideologi terbuka di era reformasi. Jurnal Office, 2(2). Retrieved from https://ojs.unm.ac.id/jo/article/view/2958/1608

Anggono, B. D. (2019). Telaah peran partai politik untuk mewujudkan peraturan perundang-undangan yang berdasarkan Pancasila. Jurnal Konstitusi, 16(4), 695. https://doi.org/10.31078/jk1642

Attamimi, A. H. S. (1990). Peranan keputusan Presiden Republik Indonesia dalam penyelenggaraan pemerintah negara; Suatu studi analisis mengenai Keputusan Presiden yang berfungsi pengaturan dalam kurun waktu Pelita I-Pelita IV. Universitas Indonesia.

Azhari, A. F. (2017). Korelasi budaya hukum dan gagasan negara hukum di Indonesia. In Imran \& F. R. Hidayati (Eds.), Etika dan Budaya Hukum dalam Peradilan. Retrieved from https://komisiyudisial.go.id/assets/uploads/files/Bungarampai-KY-2017-Etika-dan-Budaya-Hukum-dalam-Peradilan.pdf\#page=44 
Bahar, S. (1998). Risalah sidang Badan Penyelidik Usaha-Usaha Persiapan Kemerdekaan Indonesia (BPUPKI). Retrieved from https://perpustakaan.setneg.go.id/index.php?p=fstream\&fid=199\&bid=14479 \&fname $=00000001$ C.pdf

Bo'a, F. Y. (2018). Pancasila sebagai sumber hukum dalam sistem hukum nasional. Jurnal Konstitusi, 15(1), 21. https://doi.org/10.31078/jk1512

Buamona, H. (2017). Pancasila sebagai nilai dasar profesi dokter. Jurnal Hukum Novelty, 8(1). Retrieved from http://journal.uad.ac.id/index.php/Novelty/article/view/6562

Dayanto. (2013). Rekonstruksi paradigma pembangunan negara hukum Indonesia berbasis Pancasila. Jurnal Dinamika Hukum, 13(3). Retrieved from http://dinamikahukum.fh.unsoed.ac.id/index.php/JDH/article/view/253

Fajar, W. N. (2018). Pemikiran Ki Bagoes Hadikoesoemo mengenai konsep negara. Khazanah Pendidikan: Jurnal Ilmiah Kependidikan, 12(1). Retrieved from http://www.jurnalnasional.ump.ac.id/index.php/khazanah/article/viewFile/4 $059 / 2370$

Gunawan, H. (2000). M. Natsir dan Darul Islam: Studi kasus Aceh dan Sulawesi Selatan tahun 1953-1958. Jakarta: Media Dakwah.

Hardinanto, A. (2017). Autentisitas sumber sejarah Pancasila dalam masa sidang pertama Badan untuk Menyelidiki Usaha-Usaha Persiapan Kemerdekaan tanggal 29 Mei-1 Juni 1945. Veritas et Justitia, 3(1), 43. https://doi.org/10.25123/vej.2524

Hastangka, H., Armawi, A., \& Kaelan, K. (2018). Analisis Putusan Mahkamah Konstitusi Nomor 100/PUU-XI/2013 tentang Pembatalan Frasa 4 Pilar Kehidupan Berbangsa dan Bernegara. Mimbar Hukum, 30(2), 230. https://doi.org/10.22146/jmh.32660

Isdiyanto, I. Y. (2019). Dekonstruksi pemahaman Pancasila: Menggali jati diri hukum Indonesia. Yogyakarta: UGM Press.

Kaelan. (2015). Liberalisasi ideologi negara Pancasila. Jakarta: Paradigma.

Klinke, I., \& Bassin, M. (2018). Introduction: Lebensraum and its discontents. Journal of Historical Geography, 61, 53-58. https://doi.org/10.1016/j.jhg.2018.05.019

Kusuma, A. B. (2004). Lahirnya Undang-Undang Dasar 1945. Jakarta: Fakultas Hukum Universitas Indonesia.

Latif, Y. (2018a). Identitas ke-Indonesiaan dan aktualisasi Pancasila bagi generasi millenial di era digital. Jurnal Kajian Lemhanas RI, (33). Retrieved from http://www.lemhannas.go.id/images/Publikasi_Humas/Jurnal/Jurnal_Edisi_3 3_Maret_2018-min.pdf

Latif, Y. (2018b). The religiosity, nationality, and sociality of Pancasila: Toward Pancasila through Soekarno's way. Studia Islamika, 25(2). https://doi.org/10.15408/sdi.v25i2.7502

Lovin, C. R. (1967). Blut Und Boden: The ideological basis of the Nazi agricultural program. Journal of the History of Ideas, 28(2), 279. https://doi.org/10.2307/2708423

Mahanani, A. E. E. (2019). Rekonstruksi budaya hukum berdimensi Pancasila dalam upaya penegakan hukum di Indonesia. Jurnal Yustika: Media Hukum Dan Keadilan, 22(1). https://doi.org/10.24123/yustika.v22i01.1954

Maharani, S. D., Surono, Zubaidi, A., \& Sutarmanto, H. (2019). Indeks ketahanan ideologi Pancasila. Jurnal Ketahanan Nasional, 25(2). Retrieved from https://journal.ugm.ac.id/jkn/article/view/31823 
Marzuki, P. M. (2006). Penelitian hukum. Jakarta: Kencana.

Muhaimin, H. (2013). Indonesia now: Between Pancasila and crisis of democarcy in Indonesia. International Journal for Public Management and Politic Development, 1(1). Retrieved from https://pdfs.semanticscholar.org/c465/5597d12af4a0ff31353c6f441613e33c a47f.pdf

Nashir, H. (2019). Moderasi Indonesia dan ke-Indonesiaan, persfektif sosiologi. Retrieved January 30, 2020, from Republika website: https://khazanah.republika.co.id/berita/q2fnga385/moderasi-indonesia-dankeindonesiaan-perspektif-sosiologis-part1

Notosutardjo, H. A. (1965). Dari lahirnya Pantjasila sampai tjamkan Pantjasila. In H. A. Notosutardjo (Ed.), Kursus Pantjasila di depan kader-kader Pantjasila. Jakarta: Endang dan Pemuda.

Nurtjahyo, H. (2007). Negara hukum dan konstitusi: Reaktualisasi nilai-nilai ketuhanan dalam nomokrasi Pancasila. Jurnal Hukum Pantarei, 1(1).

Polamolo, S. (2018). Gelap-terang Pancasila: Otokritik atas teks sejarah yang melenceng. Jurnal Konstitusi, 15(2), 393. https://doi.org/10.31078/jk1528

Riyanto, A. (2007). Pancasila dasar negara Indonesia. Jurnal Hukum \& Pembangunan, 37(3), 457. https://doi.org/10.21143/jhp.vol37.no3.151

Shaleh, A. I., \& Wisnaeni, F. (2019). Hubungan agama dan negara menurut Pancasila dan Undang-Undang Dasar Negara Republik Indonesia tahun 1945. Jurnal Pembangunan Hukum Indonesia, 1(2). Retrieved from https://ejournal2.undip.ac.id/index.php/jphi/article/view/5511

Siswanto. (2017). Tranformasi Pancasila dan identitas ke-Indonesiaan. Jurnal Penelitian Politik, 14(1). Retrieved from http://ejournal.politik.lipi.go.id/index.php/jpp/article/download/687/492

Siswo, I. (2014). Panca azimat revolusi. Jakarta: Gramedia.

Soedarmo, U. R. (2014). Perkembangan politik Partai Komunis Indonesia (19481965). Jurnal Artefak, 2(2). Retrieved from https://jurnal.unigal.ac.id/index.php/artefak/article/view/1061

Sujasmin. (2012). Kedudukan Pancasila dalam politik hukum Indonesia menuju negara hukum kesejahteraan (Welfare Staat). $\begin{array}{llll}\text { Wawasan } \quad \text { Yuridika, 27(2). } & \text { Retrieved }\end{array}$ http://www.ejournal.sthb.ac.id/index.php/jwy/article/view/56

Syihab, M. R. H. (2012). Pengaruh Pancasila terhadap penerapan Syariah Islam di Indonesia (Universiti Malaya). Retrieved from http://studentsrepo.um.edu.my/5038/

Weatherbee, D. E. (1985). Indonesia: The Pancasila state. Southeast Asian Affairs. Retrieved from https://www.jstor.org/stable/pdf/27908524.pdf?refreqid=excelsior\%3Ae1c7 1658ac336559f2876fc262a0793b

Yunaldi, W. (2018). Rekonstruksi regulasi kesatuan masyarakat hukum adat nagari yang berbasis keadilan dalam bingkai Negara Kesatuan Republik Indonesia. Universitas Islam Sultan Agung.

Yunaldi, W. (2019). Arah pembentukan hukum tawaran paradigma hukum otentik dalam legislasi nasional. Fairness and Justice: Jurnal Ilmiah Hukum, 17(2). https://doi.org/http://dx.doi.org/10.32528/faj.v17i2.2804 